\title{
Implementation of Inquiry Method on Students' Critical Thinking Ability in the Concept of Structure and Function of Plant Networks
}

\author{
Nurlena Andalia ${ }^{1, a}$, Muhammad Ridhwan ${ }^{1, b}$, Roslina ${ }^{1, c}$, Nur Afni2,d Burhanuddin AG ${ }^{1, e}$ \\ 1 Faculty of Teachers Training and Education, Universitas Serambi Mekkah, Banda Aceh, Indonesia \\ ${ }^{2}$ Sekolah Keberbakatan Olah Raga Negeri Aceh, Banda Aceh, Indonesia \\ a nurlena.andalia@serambimekkah.ac.id; b burhanuddin@serambimekkah.ac.id \\ ${ }^{*}$ Corresponding Author \\ Whatsapp Number [+62-82274444718]
}

How to Cite: Andalia, N., Ridhwan, M., Roslina., Afni, N., AG, Burhanuddin. (2019). Implementation of Inquiry Method on Students' Critical Thinking Ability in the Concept of Structure and Function of Plant Networks. International Journal for Educational and Vocational Studies, 1(4), 373-378

\section{ARTICLE HISTORY}

Received: 11 May 2019

Revised: 18 June2019

Accepted: 25 July 2019

\section{KEYWORDS}

Inquiry Method;

Critical Thinking;

Plant Tissue Structure;

Aceh State Sports School;

\begin{abstract}
This study aims to determine the implementation of inquiry methods that can improve students' critical thinking skills on the concept of structure and function of plant tissues at the Sekolah Keberbakatan Olah Raga Negeri Aceh (Aceh State Sports School). The population of this research is the many 112 students of class XI of the Aceh State Sports School. The sample in this study were 26 students in class XI-1 as an experimental class and 26 students in class XI-2 as a control class. The method used is a descriptive method with a structural approach. Data collection is done by test techniques and data processing using the test formula. The results of the data analysis showed that the average ability or average value of class XI-1 students of the Aceh State Sports School in taking the test received 80.7. While the average value of class XI-2 students of the Aceh State Sports School in taking the test gets 70 . Based on the price of tcount and table at a significant level of $0.05 \mathrm{with} \mathrm{db}: 50$ of the sample class XI, then tcount is 6.40 and the t-table is 1.66 . So that the hypothesis proposed the implementation of inquiry methods can improve students' critical thinking skills on the concept of the structure and function of plant tissues in the Aceh State Sports School is Accepted. It is recommended that this research can increase knowledge through the use of inquiry methods in all biological science subject matter.
\end{abstract}

This is an open access article under the CC-BY-SA license.

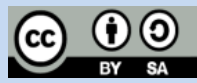

\section{INTRODUCTION}

In the world of education in general and the educational process in particular, the use of appropriate methods in teaching is very important to note, because the success of teaching is highly dependent on the suitability of the use of teaching methods to a topic being taught so that the teaching objectives are achieved well.

The method is a tool or a way to deliver learning material to students in the teaching and learning process to achieve the stated goals. According to Surachmat, (2000: 32) "The method is the way in its function is a tool to achieve goals." Furthermore Sudirjo (2001: 55) "The teaching method is a method used by the teacher in presenting learning material by paying attention to the whole learning situation to achieve the goal".

From the two opinions above it is clear that the method is a method used by the teacher in the teaching and learning process where each teacher will use certain methods in presenting learning material to students. This will make it easier to achieve the expected goals.

The learning process emphasizes providing direct experience to develop competencies in order to explore and understand the nature around scientifically. Learning natural resources and their use to improve student learning outcomes by using inquiry can help students to gain deeper understanding, critical thinking skills about natural science in general and in particular the structure and function of plant tissue.

In the process of teaching and learning required a method, the method is one way of carrying out approaches that facilitate, inspire, strengthen learning with certain 
theoretical scope. While the learning methods are procedures, sequences, steps, and methods used by teachers in achieving learning objectives.

In one approach, it can be translated into various learning methods, one of the various methods is the Inquiry method. The use of the Inquiry method can increase stimulation to students to arouse interest in learning, and to think critically in general and specifically in the use of natural resource lessons to improve student learning outcomes at the Sekolah Keberbakatan Olah Raga Negeri Aceh (Aceh State Sports School). Various problems faced by teachers in the use of learning methods are no exception in the science of biology, a problem that often arises in schools with regard to the use of methods in lessons, especially the Inquiry method. The problems faced by the teacher do not match the use of learning methods with the material being taught, giving rise to a variety of other problems, the Inquiry method is one of the methods appropriate in natural resource learning, increasing students' critical thinking skills on the concept of structure and function of plant tissue.

Every teacher should be able to use learning methods that are in accordance with the material being taught. In biology and critical thinking skills, students in class XI of the Aceh State Sports School by using the Inquiry method can make it easier for students to understand the learning material being taught, and develop creativity, and be able to educate and arouse interest in learning, and increase student learning achievement in understanding concept of structure and function of the tumbuahan network at the Aceh State Sports School.

The use of methods used by teachers in biology lessons to improve student learning outcomes, the ability to think critically in the Aceh State Sports School has not been able to create active, creative and innovative students in the learning process, there are students who are active by using the Inquiry method but not a few students who still have low grades in Biology at the Aceh State Sports School.

Biology teachers at Aceh State Sports School have not been able to use inquiry methods in lessons so that learning goals are not achieved properly and improve student learning outcomes in biology lessons. In addition, the majority of Aceh State Sports School students still have low grades in biology. This can affect the achievement of student learning outcomes as a whole. From the problems faced by biology teachers in class XI Aceh State Sports School, research needs to be carried out so that biology teachers in general can use the Inquiry method. In addition, this research is also to find alternative solutions for biology teacher in finding the causes of students' low absorption in teaching and learning activities. Based on the above problems, the authors are interested in conducting a study entitled: "Implementation of Inquiry Methods for Students' Critical Thinking Abilities on the Concept of Structure and Function of Plant Networks in Aceh State Sports School."

\subsection{Object of Study}

Based on the background of the problems mentioned above, then a problem can be formulated, namely whether the implementation of the inquiry method can improve students' critical thinking skills on the concept of structure and function of plant tissue in Aceh State Sports School?.

\subsection{The Purposes of Research}

Based on the formulation of the problem that the author has described above, the research objective is to find out the implementation of inquiry methods that can improve students' critical thinking skills on the concept of structure and function of plant tissues in Aceh State Sports School.

\subsection{Research Hypothesis}

The hypothesis of this study is: "The implementation of inquiry methods can improve students' critical thinking skills on the concept of structure and function of plant tissue in Aceh State Sports School.

\section{LITERATURE REVIEW}

\subsection{Learning Methods}

In the teaching and learning process there are various learning methods, according to Sudjana (2005: 76), the learning method is "The learning method is the method used by the teacher in establishing relationships with students during the teaching process. In addition, learning methods are ways of presenting subject matter conducted by educators so that the learning process occurs in students in an effort to achieve goals ".

From the opinions above, at this time the most widely used learning methods by teachers are some kind of lecture or explaining what is in the textbook. This portion can be around 80 percent, then the rest is a kind of practice in the laboratory, discussion, demonstration. But in this case it is proposed that students practice more directly in Biology. In addition, teachers are currently required to provide creative learning methods. The teacher might be able to use a computer and projector to display and demonstrate lessons. Helped with visualization and audio, usually the lessons learned by students will be closer to their brain. They will also be happy to listen and see the explanation of their teacher.

While Sutikno (2009: 88) states, "Learning methods are ways of presenting subject matter conducted by educators so that the learning process occurs in students in an effort to achieve goals." Based on the definition / understanding of the learning methods stated above it can be concluded that the learning method is a method or strategy undertaken by a teacher so that the learning process occurs in students to achieve goals. The purpose of the learning process is so that students can achieve competencies as expected. 


\section{Understanding the Inquiry Method}

One method of learning using a scientific approach to gaining knowledge can be done by investigating on your own. The approach to investigating in English is known as inquiry, which means question, examination or investigation.

The methods or ways of teaching there are various and different from one another, it can even be said to vary the methods of this teaching method so much, that practically as much as the number of teachers there are. A teacher should develop teaching methods that are considered good. There are several methods that can be used in applying Biological concepts.

Slamento (2003: 116) inquiry method is a way of delivering teaching materials by giving students the opportunity to learn to develop their intellectual potential in the fabric of activities that they themselves compose to find something as a convincing answer to the problems faced by them through the process of tracking data and information and thoughts that are logical, critical and systematic.

According to the English term, the inquiry method is as follows: "a technique or method used by the teacher to teach in front of the class." According to Roestiyah (2001: 71), states that the inquiry method is as follows: "The teacher divides the task of researching a problem into class, students are divided into groups, and each group gets a specific task that must be done."

The purpose of teaching with inquiry methods is for students to know and learn scientific methods and be able to transfer them to other situations. This inquiry method consists of 4 stages: 1) Stimulate students with questions, problem statements, 2) students determine the procedure of finding and collecting information or data needed to solve the questions, statements, and problems, 3) appreciate the knowledge obtained with the inquiry just implemented, and 4) analyze inquiry methods and procedures used, found to be a general method that can be applied to other situations.

The steps of the more practical inquiry method according to Suhana (2009: 77), namely:

1. Identify student needs

2. Preliminary selection of the concepts to be studied

3. Selection of materials or problems to be studied

4. Determine the roles that each student will do

5. Checking students' understanding of the problem to be investigated and found.

6. Prepare class settings

7. Prepare the necessary facilities, formulate problems formulate hypotheses, collect data, test hypotheses, draw conclusions temporarily.

8. Provide opportunities for students to conduct investigations and discoveries

9. Analyze yourself for the findings data
10. Stimulate interactive dialogue between students

11. Give reinforcement to students to be active in making discoveries

12. Facilitate participants in formulating principles and generalizing their findings.

\section{Critical Thinking Ability}

The ability to think critically is an ability that is essential for life, work, and functions effectively in all other aspects of life. According to Angelo (1995: 6) "Critical thinking must meet the characteristics of thinking activities which include: analysis, synthesis, recognition of problems and solutions, conclusions, and assessments." Thinking that is displayed in critical thinking is very orderly and systematic. Order thinking in critical thinking is a process that emphasizes the attitude of decision making which is temporary, empowers logic based on inquiry and problem solving which is the basis in assessing an action or decision making.

Critical thinking is one of the high-level thought processes that can be used in the formation of students' conceptual systems. According to Ennis (1985: 54), "Critical thinking is a way of reflective thinking that is reasonable or based on reasoning that is focused on determining what must be believed and done." The characteristics of creative thinking are as follows:

1. Able to make conclusions and solutions that are accurate, clear, and relevant to existing conditions.

2. Think openly with a systematic and have assumptions, implications, and logical consequences.

3. Communicate effectively in solving a complex problem Critical thinking is a way to make personal directed, disciplined, controlled, and corrective to yourself. This of course requires effective communication skills and problem solving methods and a commitment to change our egocentric and sociocentric paradigms.

4. Start by thinking about what and why, then look for the right direction for the answer to that question.

5. The purpose of the question is what and why

6. Specific information to answer the question above.

7. Standard criteria established to meet the answers to questions.

8. Clarity of problem /question solution.

9. Possible consequences of the choice we want.

10. Re-evaluate the results of our thinking to get maximum results, (Ennis, 1985: 54).

\section{Use of Discussion Methods}

In the opinion of Yani (2000: 23), "Every learning model has strengths and weaknesses, including discussion methods." The advantages of the discussion method are as follows: 1) Educate students to learn to express their thoughts or opinions. 2) Give students the opportunity to obtain explanations from various data sources. 3) Give the opportunity to students to experience the renewal of a problem together. 4) Stimulate students to participate 
express their own opinions, approve or oppose the opinions of their peers. 5) Fostering a feeling of responsibility regarding an opinion, conclusion, or decision that will or has been taken. 6) Develop a sense of solidarity/tolerance for opinions that vary or may conflict at all.

Discussion not only requires knowledge, being prepared and fluent in speaking but also requires the ability to speak systematically and logically. By listening to all the information stated by the speaker, students' knowledge and views on a problem will be broadened. Weaknesses of the discussion method are as follows: 1) Not all topics can be used as a method of discussion only problematic matters can be discussed. 2) In-depth discussion requires a lot of time. 3) It is difficult to determine the extent or depth of a discussion. 4) Usually not all students dare to express their opinions so that time will be wasted waiting for students to express their opinions. 5) The discussion in the discussion may be dominated by students who are brave and are used to talking. Shy and quiet students will not use the opportunity to talk.

\section{Structure and Function of Plant Networks}

Syamsuri, (2006: 123), "Plants have characteristics that are almost the same as other living things. Plants can make their own food to grow and multiply. However, the way is certainly different from living things like animals and humans. " To be able to do all that, plants have special tissues that are not found in other living things. The following is the structure and function of the tissues present in plants.

\section{METHODS}

The approach in this study uses a quantitative approach, the quantitative approach is systematic scientific research. This study is a statement that requires discussion, and solving information. This type of research is an experimental research that is research conducted by plunging directly into the field to explore and examine data relating to the implementation of inquiry methods on students' critical thinking skills on the concept of structure and function of plant tissues in the Aceh State Sports School.

\section{Population and Research Samples}

The population in this study were all students at the Aceh State Sports School of Gift Year 2017/2018 class XI Science which consisted of 6 rooms with 112 students. The sample in this study, researchers guided by the opinion of Arikunto (2006: 62). Sampling is random sampling. The way to take the sample of this research is from 6 existing rooms, researchers choose or take two classes that are considered representative of the problem raised, namely class XI1 IPA as an experimental class (taught using inquiry methods) and class XI2 IPA as a control class (taught using the method Discussion), the number of students in each class is 26 people.

\section{Data collection technique}

Data collection techniques in this study were carried out using tests. Student data collection is done by providing pretest and prostheses in the form of objective tests. Before the test was given, the question was first validated by a review team, in which the researchers took the supervisor lecturer and teacher of Biology studies at the Aceh State Sports Athletic School. After the questions are validated and choose the relevant questions to be given to students, there are 20 questions, the test can be in the form of a pretest and post test.

\section{Data analysis technique}

After the data is collected, the next step is data processing, the data collected will be processed using statistical tests that are in accordance with the hypotheses that have been formulated, namely the comparison of student learning outcomes according to Sudjana (2005) can be used statistical t-test (t test) with formula as follows:

$$
t=\frac{\bar{X}_{1}-\bar{X}_{2}}{s \sqrt{\frac{1}{n_{1}}+\frac{1}{n_{2}}}}
$$

Description :

$\mathrm{T}$ : Price t sought

$\mathrm{X} 1$ : Average grade of experimental class students

$\mathrm{X} 2$ : The mean grade of the control class students

$\mathrm{S}$ : Combined student grade standard deviation or standard deviation

n1 : Number of students in the experimental class

n2 : Number of samples in the control class

Before the data is processed, it must first be calculated the standard deviation or standard deviation and the combined standard deviation using the following formula:

$$
S=\sqrt{\frac{\sum f \cdot x^{2}}{n}}-\left(\frac{\sum f x}{n}\right)^{2}
$$

Description:

$\mathrm{S}=$ Standard deviation

$\Sigma$ f. X2 / n = Each score is squared, summed and

$\mathrm{Z}$ divided by $\mathrm{n}$

$[\Sigma \mathrm{fx} / \mathrm{n}] 2=$ The number of scores in $\mathrm{n}$ is squared

$\mathrm{n}=$ Number of Samples (Arikunto, $2006: 242$ ).

$$
S^{2}=\frac{\left(n_{1}-1\right) S_{1+}^{2}\left(n_{1}-1\right) S_{2}^{2}}{n_{1}+n_{2}-2}
$$


Description :

$\mathrm{S}=$ Standard deviation combined

$\mathrm{S} 1=$ Standard deviation of control class students

S2 = Standard deviation of the experimental class students

$\mathrm{n} 1=$ Number of samples of control class students

$\mathrm{n} 2=$ Number of sample students in the experimental class

Then to find out the implementation of inquiry methods can improve the ability of students' critical thinking on the concept of structure and function of plant tissue, then hypothesis testing is performed at a significant level of 0.10 (Arikunto: 2006: 257).

\section{RESULTS AND DISCUSSION}

Based on the results of research on the implementation of inquiry methods on students' critical thinking skills on the concept of structure and function of plant tissues in the Aceh State Sports School, the authors collected data as the first step, namely by going directly to the Aceh State Sports School of Giftedness to obtain data. In the initial stage the author gives material structure and plant tissue in class XI1 IPA (experimental class) using the inquiry method, in class XI2 IPA (control class) provides material using the Discussion method.

Then in the next stage the writer gives the same test at different times for each class consisting of 20 multiple choice questions. After giving the test student learning outcomes are complete, the authors then collect data in the form of student test results. The value of the test results can be seen in the following table 1 :

Table 1. Student Learning Achievement Value Class XI1 Science and Class XI2 Science

\begin{tabular}{cccccc}
\hline No & $\begin{array}{c}\text { Student Initials } \\
\text { (Class XI1 Science } \\
\text { as an experimental } \\
\text { class) }\end{array}$ & Value & No & $\begin{array}{c}\text { Student Initials } \\
\text { (Class XI2 IPA as a } \\
\text { control class) }\end{array}$ & Value \\
\hline 1 & 2 & 3 & 4 & 5 & 6 \\
\hline 1. & AR & 80 & 1. & AH & 75 \\
\hline 2. & CH & 75 & 2. & FZ & 65 \\
\hline 3. & DF & 80 & 3. & IF & 75 \\
\hline 4. & FH & 70 & 4. & JL & 65 \\
\hline 5. & HM & 100 & 5. & MW & 80 \\
\hline 6. & KH & 70 & 6. & MR & 70 \\
\hline 7. & MB & 85 & 7. & NS & 80 \\
\hline 8. & MB & 65 & 8. & NR & 65 \\
\hline & & & & & 6 \\
\hline
\end{tabular}

\begin{tabular}{|c|c|c|c|c|c|}
\hline 9. & MR & 80 & 9. & NK & 65 \\
\hline 10. & $\mathrm{NN}$ & 95 & 10. & $\mathrm{PZ}$ & 80 \\
\hline 11. & NM & 65 & 11. & $\mathrm{SH}$ & 65 \\
\hline 12. & NM & 90 & 12. & SR & 80 \\
\hline 13. & NR & 75 & 13. & SM & 60 \\
\hline 14. & NA & 75 & 14. & SR & 70 \\
\hline 15. & PN & 75 & 15. & WS & 70 \\
\hline 16. & SR & 85 & 16. & DM & 65 \\
\hline 17. & $Y z$ & 75 & 17. & ES & 65 \\
\hline 18. & $\mathrm{YH}$ & 85 & 18. & FD & 60 \\
\hline 19. & ZK & 75 & 19. & $\mathrm{HR}$ & 75 \\
\hline 20. & ZP & 85 & 20. & $\mathrm{KH}$ & 70 \\
\hline 21. & $\mathrm{NH}$ & 85 & 21. & Ml & 80 \\
\hline 22. & $\mathrm{NL}$ & 90 & 22. & NF & 50 \\
\hline 23. & $\mathrm{RI}$ & 85 & 23. & RK & 75 \\
\hline 24. & $\mathrm{RR}$ & 75 & 24. & RJ & 85 \\
\hline 25. & $\mathrm{RM}$ & 100 & 25 & $\mathrm{RH}$ & 65 \\
\hline \multirow[t]{3}{*}{26.} & $\mathrm{DR}$ & 80 & 26. & SF & 65 \\
\hline & Jumlah & 2100 & & Jumlah & 1820 \\
\hline & Nilai Rata-rata & 80,7 & & Nilai Rata-rata & 70 \\
\hline
\end{tabular}

Based on the results of the study, the significant level $\operatorname{sig}=0.05$ and degrees of freedom $(\mathrm{dk})=(\mathrm{n} 1+\mathrm{n} 2-2)$, then the distribution table t obtained was 1.66. At the significant level of 0.05 with $\mathrm{dk}=50$ is 1.66 while the value of $\mathrm{t}$ is 6.40 so that alternative hypotheses can be accepted

\section{Review of Hypotheses}

Based on the $t_{\text {count }}$ and table prices at a significant level of 0.05 with $\mathrm{db}=50$ are from the sample class XI of the Aceh State Sports Athletic School, then the tcount is 6.40 and the table is 1.66 then the alternative hypothesis $(\mathrm{Ha})$ reads:

Implementation of inquiry methods can improve students' critical thinking skills on the concept of structure and function of plant tissues in the Aceh State Sports School, this hypothesis is accepted.

\section{Discussion}

Based on the results of the study, then the implementation of inquiry methods on critical thinking skills on the concept of network structure and function in class XI1 IPA and XI2 IPA provide different learning outcomes in obtaining grades as learning outcomes. Class XI1 science students taught using the Inquiry method are better at learning outcomes than class XI2 science.

This is known from the acquisition of the highest value, namely class XI1 IPA is 100, while class XI2 IPA is 90. From the author's observation, students of class XI1 IPA 
(Experiment class) are more creative in learning, easy to understand the material delivered by the teacher. Students of the XI1 Science experimental class, initially students assumed that this learning model was just an ordinary discussion method, which basically only divided them into several study groups. But students are very interested or impressed when they see that this learning model is most preferred by students with the equal distribution of tasks, responsibilities, in other words such as group members having the same task to solve problems given by the teacher.

The effectiveness of learning Biology Science by implementing inquiry methods on students' critical thinking skills on the concept of structure and function of plant tissues in class XI1 of the Natural Sciences School of Aceh State Sports. While the control class (XI2 IPA) seems like ordinary learning, there are no new actions that can be felt by students on the material structure and plant tissue, from the students' responses that are not so enthusiastic, students are considered this learning model as usual discussion, what stands out are the students active students, or students who have motivation that play a role in learning, while other students just go along and be impressed as it is, without any particular arguments in learning.

From the data obtained from the student's ability test conducted in class XI IPA of the Aceh State Sports School, the researcher concluded that the implementation of the inquiry method of students' critical thinking skills on the concept of structure and function of plant tissues carried out in class XI1 IPA as an experimental class gave results better learning than without using inquiry methods conducted in class XI2 IPA as a control class.

\section{CONCLUSION}

The implementation of inquiry methods on students' critical thinking skills can improve student learning outcomes in the concept of the structure and function of plant tissues in class XI1 of the Aceh State Sports School. Student learning outcomes (grades) are higher in grades (100) than student learning achievements in the control class (classes taught without using the inquri method) on the concept of network structure and function in class XI1 of the Aceh State Sports School. Means the proposed hypothesis (Ha) is accepted. of tcount is greater than the value of ttable (6.40> 1.66). This hypothesis states that there is a significant influence on student learning outcomes in the learning process of network structure and function in the Aceh State Sports School can be accepted.

\section{REFERENCES}

Arikunto, S, (2006). Prosedur Penelitian, Jakarta : Rineka Cipta

Anggelo, (1995). Kemampuan Berpikir Kritis, Jakarta: Rosda Karya

Ennis, (1985). Pembentukan Sistem Konseptual Siswa, Bogor: Sinar Baru

Roestiyah, (2001). Kebijakan Metode Inquiry, Bandung : GrafikaSanjaya, 2008. Tiori Metode Pembelajaran, Jakarta: Kencana Prenada Media Group

Slamento, (2003). Motivasi dan Prestasi, Jakarta: Rosda Karya

Sudirjo, (2001). Strategi Pembelajaran, Jakarta : Balai Pustaka

Sudjana, (2005). Tujuan Intruksional, Medan : Univestas Sumatra Utara

Suhana, (2009). Model Pembelajaran Kooperatif. Jakarta: Rosda Karya

Sutikno, (2009). Karateristik Metode Pembelajaran, Jakarta: Erlangga

Syamsuri, (2007). Natural Sciences Biology. Jakarta: PT Elangg

Surachmat, W, (2000). Metode Pembelajaran Diskusi, Jakarta:Balai Pustaka Syamsuri,

(2006). IPA Biologi, Jakarta : Erlangga

Yani, A, (2000). Metode Pembelajaran Aktif, Surabaya : Bina Aksara. 